obvious choice as President from 1982. From 1952 he was assistant editor (to Gordon Childe), and from 1956 until 1997 sole editor, of Anatolian Studies, the Institute's journal. He was awarded an honorary Doctorate of Higher Letters from Chicago (1991), doubtless in part for his contribution of lexical material from tablets in the Ashmolean to the series Materials for the Sumerian Lexicon and the Chicago Assyrian Dictionary. Other honours included Foreign Membership of the Royal Danish Academy of Science and Letters (1976), and election as a Freeman of the City of Norwich.

With exaggerated modesty he once described himself as "just a bookworm". This was not true at all. Those who knew him will remember him, on the contrary, as a meticulous and energetic scholar of ample learning, always ready to engage with others, or to be enthused by new discoveries. But above all, we remember him as a generous teacher, and a kind and dear friend.

$\mathrm{He}$ is survived by his wife Diane, whom he married in 1957, and stepdaughter Caroline.

J. A. Black

Expanded from an obituary which appeared in The Times, 24th January 2001.

\title{
Miss Geraldine Talbot M.A.
} (1908-2000)

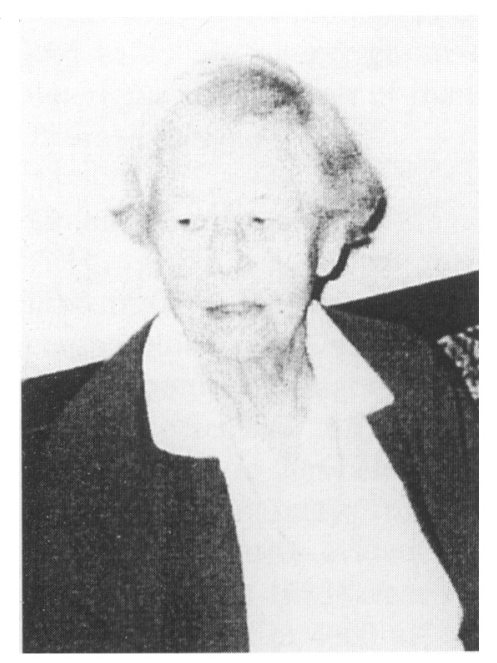

We remember Gerry here especially for her more than 20 years of devoted service to the British School of Archaeology in Iraq, first as Assistant Secretary for Publications, and from 1963 to 1976, Honorary Secretary during the occasionally difficult period when the School had finally achieved its full establishment in Baghdad. She then resumed her responsibility for the School's publications until her final retirement in 1983, but she never lost her interest in its affairs. We all look back with gratitude for Gerry's constant and loyal support. She never failed us and she never fussed. We remember her with great affection.
Gerry Talbot died on September 19,2000 at the age of 92, after a short illness following a fall at her home.

After reading Modern Languages at Oxford, Gerry served with the First Aid Nursing Yeomanry as a military ambulance driver throughout the blitz, largely in dockland and south-east London, and was then commissioned into the Auxiliary Territorial Service with the rank of captain. In 1946 she became Assistant Librarian at the Institute of Archaeology, University of London and, after the retirement of Joan du Plat Taylor, Librarian from 1962 to 1976 . All of us at the Institute during that time owe her a great debt for her cheerful readiness to help staff, students and visiting scholars alike with their problems, great or small, over the whole field of archaeological literature, of which she had an extraordinary knowledge. On the practical side, she had experience on British digs, but her own main interest lay in the Near East, where she took part in excavations at Busairah, Petra, Jerusalem and Jericho.

David Oates 